1919, number. We also note that that most useful publication, Michel's (once Nagel's) Jahresbericht, has ceased to exist. At the close of the war it was announced that a single volume covering the period of the war was in preparation.

\title{
Help for the Blind
}

The text of the Government Bill to promote the welfare of blind persons, which came into operation on September 10, 1920, deserves universal approval. Its chief provision is that every blind person who has attained the age of 50 shall be entitled to such pension as, under the Old Age Pensions Act, 1908 to 1919 , he would be entitled to if he had reached the age of 70. But that is not all. County and Borough Councils are authorized to provide and to maintain or to contribute towards workshops, hostels, homes, or other places for the reception of the blind. With the approval of the Minister of Health, they may make such further arrangements for the welfare of blind persons as they may think fit. The measure applies to Scotland and to Ireland. Its short title will be "The Blind Persons Act, 1920."

In this connection it may be noted that a memorandum has been issued by the Board of Education dealing with the training of blind students. The chief object of the Board is to provide a link between the special school giving primary education, on the one hand, and the workshop, on the other. The Board is prepared materially to increase the grants it makes in aid of training institutions, and these and other grants mentioned in the memorandum will be retrospective as from April 1, 1919.

\section{INTERIM REPORT OF THE JOINT COMMITTEE APPOINTED BY THE ILLUMINATING ENGINEERING SOCIETY TO ENQUIRE INTO "EYE-STRAIN IN CINEMAS "*}

THIS Committee was formed in response to a request conveyed to the Illuminating Engineering Society from the London County Council (April 28, 1919) for information as to possible causes of eye-strain in cinemas, and the best means of removing them, and in particular "The question of the strain on the eyes caused by the proximity of seats to the screen at cinematograph halls, and of the possibility of devising some means of lessening the ill-effects

* Reprinted from the Illuminating Engineer, June, 1920. 